p-ISSN 1693-1246

e-ISSN 2355-3812

January 2018
Jurnal Pendidikan Fisika Indonesia 14 (1) (2018) 7-17

DOI: $10.15294 / j p f i . v 14 i 1.8259$

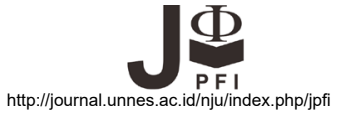

\title{
IMPACT OF LEARNING EARTH LITOSPHERE USING INTERACTIVE CONCEPTUAL INSTRUCTION ON LOGIC THINKING, CONCEPTUAL UNDERSTANDING, AND SPIRITUAL ASPECT EMBEDDING
}

\author{
H. Johan ${ }^{1,2 *}$, A. Suhandi ${ }^{3}$ A. R. Wulan ${ }^{4}$, Sipriyadi $^{5}$ \\ ${ }^{1}$ Physics Education Study Program, FKIP, University of Bengkulu, Indonesia \\ ${ }^{2}$ Graduate School, Doctoral Program of Science Education; Indonesian Education University, Indonesia \\ ${ }^{3}$ Department of Physics Education, FPMIPA, Indonesian Education University, Indonesia \\ ${ }^{4}$ Department of Biology Education, FPMIPA, Indonesian Education University, Indonesia \\ ${ }^{5}$ Department of Biology, Faculty of Mathematics and Natural Sciences, University of Bengkulu, Indonesia
}

Received: 20 June 2017. Accepted: 8 October 2017. Published: 1 January 2018

\begin{abstract}
The aim of this study is to explore the impact of interactive-conceptual-instruction with visualization on logic thinking, conceptual understanding and spiritual aspect embedding. The sampling technique used in this research was convenience sampling. This research used mixed methods with embedded experiment design. The data of logic thinking and conceptual understanding was collected through pre-test and post-test. The questionnaires were used to collect data on spiritual attitudes and were analyzed qualitatively. The results showed that logic thinking-ability improves from no logic thinking to inductive-deductive logic thinking. The improvement of logic thinking abilities was in the medium category. Understanding the concept shifted from incompetent to conceptual understanding with improvement, in the medium category. The questionnaires analysis showed that the students got spiritual values related to the awareness of God believing behind the natural phenomena that impact on their spiritual attitudes. This study also tried to apply the results of pure science research to support learning activities. Based on the result of the research, it can be concluded that the learning process using interactive conceptual with visualization can improve logic thinking, conceptual comprehension, and spiritual attitude embeding.
\end{abstract}

\section{ABSTRAK}

Penelitian ini bertujuan untuk mendeskripsikan pengaruh pembelajaran litosfer menggunakan interaktif konseptual berbantuan visualisasi dalam meningkatkan kemampuan bernalar, pemahaman konsep, dan untuk menanamkan aspek spiritual. Teknik sampling pada penelitian ini menggunkan convenience sampling. Penelitian ini menggunakan mixed methods dengan embedded experiment design. Data penalaran dan pemahaman konsep dikumpulkan melalui pretes dan postes. Kuisioner digunakan untuk mengumpulkan data tentang sikap spiritual dan dianalisa secara kualitatif. Hasil penelitian menunjukkan bahwa kemampuan penalaran bergeser dari tidak ada penalaran menuju penalaran induktif-dedukti. Peningkatan kemampuan bernalar berada pada kategori sedang. Pemahaman konsep bergeser dari tidak kompeten menuju paham konsep dengan peningkatan berada pada kategori sedang. Analisis kuisioner menunjukkan mahasiswa mendapatkan nilai spiritual terkait kesadaran akan sifat Ketuhanan yang ada dibalik fenomena alam yang berdampak pada sikap spiritual mereka. Penelitian ini juga mencoba untuk mengaplikasikan hasil penelitian sains murni dalam mendukung kegiatan pembelajaran. Berdasarkan hasil penelitian maka dapat disimpulkan bahwa proses pembelajaran menggunakan interaktif konseptual berbantuan visualisasi dapat meningkatkan penalaran, pemahaman konsep, dan menanamkan sikap spiritual.

\section{(c) 2018 Jurusan Fisika FMIPA UNNES Semarang}

Keywords: Conceptual understanding; Conceptual interactive; Logic thinking; Lithosphere; Spiritual attitudes

\footnotetext{
*Correspondence Address:

Jln Wr. Supratman, Kandang Limun, Bengkulu

E-mail: hennyjohan88@gmail.com
} 


\section{INTRODUCTION}

Learning everything about nature is important. Earth and Space Science (ESS) is one branch of science that studies many things about nature and its various phenomenon. Studying the ESS including the earth lithosphere can help understanding the various natural phenomena. In addition, learning ESS can help to determine the appropriate natural disaster mitigation rescue, raise awareness in the use of nature source, act wisely to nature, and realize the greatness of God as the creator of nature (Bayong, 2014). The concept of earth is imaginary, in another sense it can not be observed directly (Sunderlin, 2009), including the concept of the earth lithosphere. Character of the concept that most difficult to observe directly makes the learners difficult to understand and redistribute the concept. This difficulty affect learners' conceptions so that there are various alternative conceptions other than scientific conception (Miller \& Brewer, 2010; Joley et al., 2012). Explaining the concept of the earth lithosphere can utilize various visualizations e.g. in the form of animation.

Earth Lithosphere concepts that can not be observed directly require right constructed learning in order to train the ability in logic thinking. Beside analogy, several research results suggests conceptual thinking can be developed during the exploration process of concept representation, for example in the image and animation visualization ( Prain, Tytler, \& Peterson , 2009 ; Smith \& Bermea, 2012 ). Analogy, scientific models and graphic representations have been used in geology learning to improve students' logic thinking (Smosna \& Bruner, 2007; Sibley, 2009; Jee et al., 2010). Visualizing the concept of lithosphere using animation and videos can be done to facilitate students' logic thinking on the concept. Visualization can also utilize the results of authentic data analysis from the results of research in the field of pure physics science. The literature study shows that there has not been much reported on research collaboration in science research and learning research, especially in Indonesia.

Various natural phenomena that occur in the lithosphere can be felt and it shows great of God then learning of the earth lithosphere can be constructed by using various visualization to build logic thinking in understanding the concepts at the same time for embedding a religious attitude as more aware of the Majesty and the existence of the Creator, the responsibility for maintaining nature and become a mercy for nature and all other living things. Based on literature studies have not been widely reported on the integration of spiritual values, especially the attitude of belief in God in science learning .

Pavio said that according to the dual coding theory, human cognition system consists of two stems of cognition namely verbal system and visual system (Soesanto, 2009). Representations that belong to the visual class are images (including virtual simulations), graphs, tables, and mathematical formulas. Representation of images, simulations, graphics, tables nor a mathematical formula in the text or in learning can improve brain memory because of the existence of such representation facilitates to the power of dual coding memory. Facilitating learners to explore their representational skills can lead them to understanding science conceptually (Bowen, 1998). According to Presseisen, thinking is a cognitive process including perception, logic thinking, and intuition (Costa, 1988).

Visualization media, especially animation, is needed to help to visualize the concepts of earth that can not be observed directly. Logic thinking can be developed by analizing concepts with a scientific model to understand a

Table 1. The basic process of thinking skills according to Presseisen in Costa (1988) .

\begin{tabular}{|c|c|c|}
\hline Skills thinking & Explanation & Ability \\
\hline Cause and effect & Establish cause and effect & Predict, infer, decide, evaluate \\
\hline Transformation & $\begin{array}{l}\text { A known character relationship } \\
\text { with an unknown character }\end{array}$ & Analogy, metaphor, logical induction \\
\hline Correlation & Detects regular operations & $\begin{array}{l}\text { Ability: partial and overall, pattern, anal- } \\
\text { ysis and synthesis, sequence, logical } \\
\text { deduction }\end{array}$ \\
\hline Classification & Determining quality in general & $\begin{array}{l}\text { Similarities and differences, grouping } \\
\text { and selecting, comparing }\end{array}$ \\
\hline Qualification & Getting unique characteristics & $\begin{array}{l}\text { Unique on basic identification, defini- } \\
\text { tion, fact, repetition }\end{array}$ \\
\hline
\end{tabular}


concept (Sibley, 2009). Beside anology, some research suggests analogy of logic-thinkingconcepts can be developed during the process of exploration of the concept representation (Prain et al., 2009; Smith \& Bermea, 2012).

Analogy, scientific models, and graphic representations have been used in geology learning to improve student logic thinking (Sibley, 2009; Jee et al., 2010; Smosna \& Bruner, 2007). According to Presseisen, thinking is cognitive process that is a mental activity to build knowledge (Costa, 1988). Those cognitive processes are perception, logic thinking, and intuition. The basic process of thinking can be seen in Table 1 .

Science can bring a changing in life of materially and religion can bring about a spiritual changing. Science certainly can not replace religion. However, if science and religion are combined then it can perform the task scientifically as well as improve the spiritual attitude so as to form a whole person. The separation of science from religion can lead to a loss of value and control over the axiom aspects of science. This can cause losses. Studying the explicit knowledge in Islamic religious teaching can be approached with science, it is growing rapidly in European Countries. They think Islam is a scientific study (Bayong, 2012). Thus, it can be said that religious teaching, especially Islamic can get closely related to science.

Some ways which can be done to teach concepts to prospective students teachers are: using the form of analogies. The teacher's ability on representation supports to be able to create more meaningful learning in order to train logic thinking. The results also reveal that the use of various right representation can train logic thinking-skills (Ainsworth, 1999; Meij \& Jong, 2003); the shifting of learners' concepti- on can be seen and explained through graphic representation (Wittmann, 2006); technology can be used as a bridge between concepts practically (Newhouse, Lane, \& Brown, 2007).

Based on these descriptions, the research aimed to describe the influence of lithosphere learning using conceptual interactive visualization aid in improving logic thinkingability, concept comprehension, and spiritual aspect embeding.

\section{METHOD}

This research was conducted in one of the institution in Bengkulu that conducted Physics Education Study Program. The sampling was done by means of convenience sampling because there was only one class for the class of 2015 which was the subject of the research. Instruments in this study consist of: test of concepts mastery in the form of multiple choice questions to know the level of students mastery to the concept of earth lithosphere, the logic thinking-abilities test in the form of essays with the criteria of reasoning refers to the reasoning criteria by Furtak (2010), questionnaires and open-ended test to know the students' spiritual attitude after learning Earth and Space science.

This research used mixed methods of embedded experiment design. The implementation stage used one pre- and post-test design.

The first stage was a study and needs analysis, at this stage analyzed the concept in the material earth litosphere and animation that can be developed to support learning activities to improve the scientific reasoning and mastery of the concept. Earth lithosphere concepts were also explored to express the spiritual values contained within them. The second stage

Table 2. Reasoning Criteria Adapted From Furtak

\begin{tabular}{lll}
\hline Category & Score & Explanation of indicators \\
\hline $\begin{array}{l}\text { Logic thinking based on Induc- } \\
\text { tive-deductive rules }\end{array}$ & 4 & $\begin{array}{l}\text { Reasons consist of comprehensive data analysis } \\
\text { supported by relevant principles, theories, laws, or } \\
\text { definitions of data / problems solved. } \\
\text { Reasons have been made based on some data (in- } \\
\text { cluding data implicit) and applied data analysis. But } \\
\text { not enough to solve the problem }\end{array}$ \\
$\begin{array}{lll}\text { Logic-thinking based on data } \\
\text { No logic-thinking }\end{array}$ & 2 & $\begin{array}{l}\text { The statement relies on limited data or on the sur- } \\
\text { face features of the problem } \\
\text { If there is a statement then it is just a repeated state- } \\
\text { ment and not clear }\end{array}$ \\
Unidentified & 1 & Answer sheet empty \\
\hline
\end{tabular}




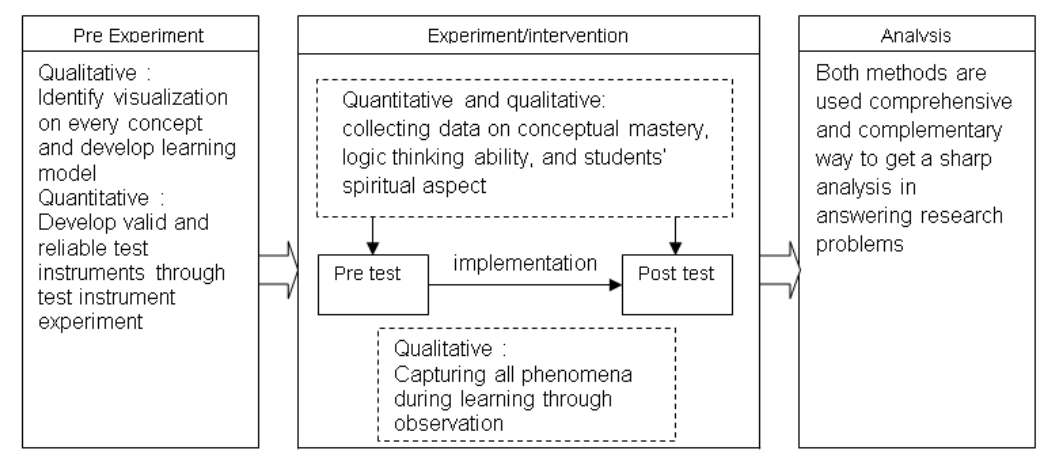

Figure 1. Design of embedded experiment (Creswell \& Clark, 2007 )

focused on the design of the program, at this stage developed conceptual interactive learning using visualization and all learning tools. The final stages of learning is given a series of questions until it cannot answered to embed belief in the nature of God. The third stage was the implementation of the program. This stage used a one-pretest-posttest design research design. At the end stage, performed processing and data analysis with conclusion. The results of questionnaires and testimony of student responses were analyzed qualitatively. Data analysis of the result of logic thinking ability test was done by using analysis technique developed by Furtak. The reasoning criteria of reasoning in this study refers to the analytical technique that developed by furtak (2010) where scores, descriptions and reasoning criteria can be seen in Table 2 .

The normalized gain formula (N-Gain) is used to calculate the increase that occurs before and after the learning. The formula used is as follows: (Meltzer, 2002)

$$
<g>=\frac{S_{\text {post }}-S_{\text {pre }}}{S_{\text {Max }}-S_{\text {pre }}}
$$

Notes:

$$
\begin{aligned}
& S_{\text {post }} \text { : Final test score, } \\
& S_{\text {pre }} \text { : Initial test score, and } \\
& S_{\text {maks }} \text { : Maximum score }
\end{aligned}
$$

Table 3. Category of N-Gain Level (Meltzer, 2002)

\begin{tabular}{cc}
\hline Limitations & Category \\
\hline$g>0.7$ & High \\
$0.3 \leq g \leq 0.7$ & Medium \\
$g<0.3$ & Low \\
\hline
\end{tabular}

After that, the value of $\mathrm{N}$-gain from inc- reasing in the final test value of the initial test score was calculated.

The learning activities in this study adapted conceptual interactive instruction (ICI) approach. In the research field, a special step was added at $\mathrm{ICl}$ approach to embed a spiritual attitude that is Chain Till Unanswered Question. In general, learning activities followed the design as in Table 4.

Table 4. Design of learning activities

Concept Focus:
Presentation and scientific
explanation using visualization
media

\section{Use of Text:}

Textbooks are used to find keywords relate to learned concepts

Research Based Materials: Utilizing research results in Class room interaction: Discussions were conducted throughout the learning activities the field of geophysics in learning activities

\section{Chain Till Unanswered Question}

Presented a phenomenon then students are given serial questions that can be answered scientifically to question that can not be answered scientifically so back to the statement that God is all.

\section{RESULTS AND DISCUSSION}

The ability of reasoning and mastery of concepts

The discussion is more focused on the effect of applied learning that has been applied to logic thinking, conceptual understanding, and embedding the spiritual attitudes in the learning process. Analysis of research data for logic thinking and mastery of concepts was done by looking at differences in initial test scores before implementation and final test scores after implementation. Table 5 showed that the 
increase of students' logic thinking-conditions was quite good with an average $\mathrm{N}$-gain of 0.69 in the medium to upper (upper-medium) category. The improvement of students' concept mastery was also quite good with the average $\mathrm{N}$-gain of 0.59 being in medium category. Based on Table 5, it can be seen that the improvement of concept mastery and logic thinking are in the same range, medium. The difference of $\langle\mathrm{g}\rangle$ increasing logic thinking-aspects and concepts mastery for each student can be seen in Figure 2

Table 5. Average $\mathrm{N}$-gain after implementation of Earth and Space Science lecture program

\begin{tabular}{lcl}
\hline Aspect & $\begin{array}{c}\text { Average } \\
\text { N-gain }\end{array}$ & Category \\
\hline Logic thinking & 0.69 & Medium \\
Mastery of concept & 0.59 & Medium \\
\hline
\end{tabular}

Based on Figure 2 it can be seen that the improvement of logic thinking ability and conceptual ability of each student on lithospheric material varies. Overall, there is a pattern where the improvement of both aspects is synergy. In general, students who have a good increase in logic show a tendency to increase the mastery of a good concept as well. In line with Carolan, Prain, and Waldrip statement (2008), which revealed that the learning activities that focus on the ability in thinking and logic thinking enables learners to understand concepts in more depth. $\mathrm{N}$-gain distribution of each student for logic thinking ability and mastery of concept as result of implementation activity of Earth and Space science lecture program can be seen in Table 6 .

Table 6. N-Gain distribution of each category

\begin{tabular}{cccc}
$\begin{array}{c}\text { N-Gain } \\
\text { Restric- } \\
\text { tions }\end{array}$ & $\begin{array}{c}\text { Cate } \\
\text { gory }\end{array}$ & Reasoning & $\begin{array}{c}\text { Mastery of } \\
\text { concept }\end{array}$ \\
\hline $\begin{array}{c}g>0.7 \\
0.3 \leq g\end{array}$ & High & 9 students & 6 students \\
$\leq 0.7$ & Medium & 15 students & 18 students \\
$g<0.3$ & Low & There is no & There is no \\
\hline
\end{tabular}

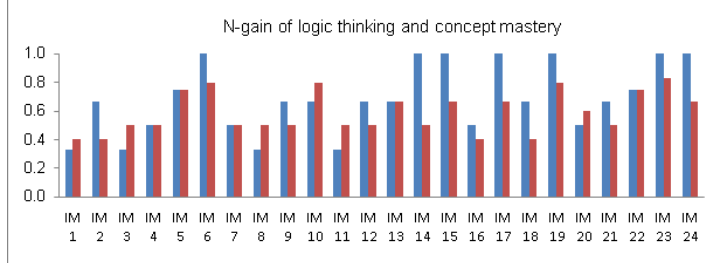

Figure 2. Improved logic thinking and mastery of each student after implementation

Notes; Blue = logic thinking; Red $=$ concept mastery

In the medium category of $\mathrm{N}$-gain distribution for logic-thinking are: $\mathrm{N}$-gain values $0.6 \leq$ $\mathrm{g} \leq 0.7$ of 7 students, $0.4 \leq \mathrm{g} \leq 0.6$ of 4 students, and $0.3 \leq \mathrm{g} \leq 0,4$ as many as 4 students. It appears that for logic-thinking ability, the largest distribution of students is in the upper-medium range. $\mathrm{N}$-gain distribution for conceptualization is $0.6 \leq \mathrm{g} \leq 0.7$ for 5 students, $0.4 \leq \mathrm{g} \leq 0.6$ for 13 students, $0.3 \leq \mathrm{g} \leq 0.4$ none. The distribution of students' concept mastery is in medium category. From the distribution of students in each category $\mathrm{N}$-gain it can be seen that the increase in students' logic-thinking is mostly in the medium and high category. The distribution of $\mathrm{N}$-gain in each category indicates that the learning of lithosphere that has been developed has a good impact in increasing the logicthinking and mastery of student concepts. The distribution of students on post-test results for each level of logic-thinking can be seen in Table 7 .

The average of students logic-thinking ability before implementation activities were in category of no logic-thinking. This indicates that before the implementation activity the students' logic-thinking ability is in the category of no logic-thinking. After the implementation of lecturing program, the average of students logic-thinking capability were in the category of logic-thinking based on the evidence. As for the mastery of the concept is also seen the difference between the conditions before and after implementation. These results can indicate that the learning activities have an impact in accor-

Table 7. Distribution of the number of students at each level of logic thinking

\begin{tabular}{cccc}
\hline $\begin{array}{c}\text { Logic think- } \\
\text { ing scores }\end{array}$ & K ategori & $\begin{array}{c}\text { Before } \\
\text { implementation }\end{array}$ & $\begin{array}{c}\text { After } \\
\text { implementation }\end{array}$ \\
\hline 4 & Deductive-inductive logic-thinking & 0 & $29.2 \%$ \\
3 & Logic-thinking with evidence & 0 & $37.5 \%$ \\
2 & Logic-thinking with data & 0 & $33.3 \%$ \\
1 & No logic-thinking & $70.8 \%$ & 0 \\
0 & Undefined & $29.2 \%$ & 0 \\
\hline
\end{tabular}


dance with the objectives of the study.

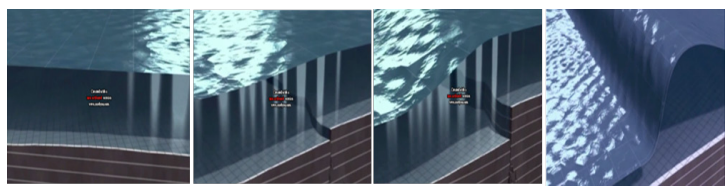

Figure 3. The animation of tsunami waves.

Based on the phenomenon captured during the learning activity through observation, the logic-thinking improvement and mastery of the concept is quite satisfactory after learning lithospheric material is thought to be caused by several factors, they are visualization media (graphs, diagrams, drawings, animations) used, interaction activities that occur in the class in the form of questions and feedbacks between fellow students guided by lecturers, and the use of science research as a research based material in learning activities.

The results of observation during the learning activities show that the visualization media used in the lecture activity is able to visualize the partial that compose a natural phenomenon in litosphere concept. Media visualization is supposed to help students to distribute the concepts taught because it is able to explain the correlation between several concepts (Werts Scott, 2011). Visualization media, especially animation, can show clearly how concepts are interconnected in a natural phenomenon within the scope of lithospher. In addition, it can show how a phenomenon process occurs in each stage. Animation explaining one phenomenon allegedly can help students understand several concepts simultaneously as well as require various concepts to explain a natural phenomenon. Benzen (2016) states that animation supports learning activities more effectively.

Examples of animation used in learning that helps students to more easily understanding concept is animation that visualizes how tsunami waves can be formed when the earthquake. Based on the recorded phenomenon during the learning through observation, it is known that students initially understand tsunami waves as secondary wave propagation on water medium. In fact, secondary waves are transverse waves that do not propagate in fluids. The stages in the animation that visualize the occurrence of tsunami waves help students understand the cause of the tsunami wave well. The animated footage of the tsunami wave used in the learning activities can be seen in Figure 3.

The animated trailer in Figure 3 can pro- vide an understanding that the tsunami wave is basically a wave of water that occurs due to wear at the time of shifts and fractures. It is seen that there is a relationship between fault energy and the magnitude of the resulting tsunami wave. The greater the energy released by the fault as the source of the earthquake the greater the tsunami wave generated. In addition, there is also a relationship between the form of fault/faults on the occurrence or absence of tsunami waves. Presseisen in Costa (1988) reveals that one of thinking ability is the correlation (connected) includes partial and overall thinking ability, patterns, analysis and synthesis, sequencing and logical deduction.

The use of visualization is primarily animation that can show the relationship between variables, (eg in the animated trailer Figure 3 ) the strength of the fault source, the fracture shape with the magnitude of the wave is supposed to facilitate correlation thinking ability, thus giving effect to the mastery of student's concept and reasoning. This is supported by the results of research by Doyan \& Sukmantara (2014) which shows that intranet web is designed by incorporating visualization and one of them is animation can improve students' concept understanding. Student response also showed similar.

Result of qualitative analysis of students' comments/response on learning activities show that according to the students, the used of animation as a media in the learning context have an impact, they are : helping students think cause and effect and relationships between concepts ; a very clear animation help simplify logic-thinking concepts and then understanding the concept for learning Earth and Space Science really need logic-thinking and imagining because it can not be observed directly; complicated concept becomes easier because it looks visualization concept; support learning activities because the visualization media is in accordance with the learning that is done; and helping think more spacious and open.

Werts \& Hinnov (2011), in their research, brings its three-dimensional visualization in the form of a graph from matlab to teach insolation reported that an increase in test scores of more than $32 \%$ better than in a conventional classroom. The inclination of the angle to come will give a different image indicating the amount of insolation. Visualization is able to explain the connection of various variables. For example, based on the image of the matlab is illustrated latitut relationship to the magnitude insolation. 
In addition, based on the recorded phenomenon during learning activities it is known that the animation media makes students has an appeal and curiosity so that it creates a very active class interactions in the form of questions and feedbacks between students and students with the lecturer.

This is in line with Ismawati et al. (2014), who state that visualization in the form of demonstration before the learning raises students' curiosity. This interactive activity and the visualization of various lithosphere phenomena make learning more enjoyable. This is supported also by the results of the qualitative analysis of responses/comments given by students on the learning activities, according to the student: using animation makes learning activity not bored and fun; interactive living class ; the lecturers are able to master the classroom and make the atmosphere a good one; visualization give details of the concept (phenomenon) clearly raises students' curiosity and questions from students; and shows students' interest towards learning Earth and Space Science.

This is supported by Lowe (2004) who states that visualization in the form of animation can provide situational dynamics with a very clear picture and this has the potential to support learners thinking logically. Kali (2003) shows a similar thing where virtual visualization used as a game in learning activities proved able to increase students' enthusiastic or interest learning. Supported also by the Kastens' statement (2010) which states that the learning activities of geoscience using a lot of visualization can provide motivation and encourage to like learning geosains.

The same thing is expressed by students in their responses where lithospheric learning using visualization raises enthusiasm and interest in Earth and Space scince. The existence of a fun learning atmosphere, interest and curiosity about the concept of lithosphere that has been taught allegedly also contributed to concepts mastery and students' logic-thinking of lithosphere material.

The interest raised by the used of visualization media in learning activities thought to be the reason for the appearance of curiosity and questions that make learning to be very active and interactive. This is in line with the student's response to learning activities which states that the visualization in the learning activities make more spirit, interesting, not bored, and so more curious. In line with Mc Connell \& Khatrien (2011) who revealed that motivation is one of the factors supporting the success of a learning process.

In addition to the visualizations discussed earlier, improvements in conceptualization and reasoning are also influenced by the visualization media at the research-based material stage in the lecture program (conceptual interactive with visualization) that has been developed. Based on the predicted phenomenon in the learning activity, visualization of the science research results presented at the research-based material stage has the potential to facilitate the students to get a rill of subsurface conditions that represent the concept of the subsurface structure studied in the lithosphere material.

Learning experience by presenting the results of science research allegedly attract attention and curiosity and to understand more about the concept of lithosphere because it is directly related to natural conditions. In line with Ellwein et al., (2014) which discloses authentic scientific data from scientific research results can provide an interesting learning experience. This interest certainly brings its own motivation to study the earth and space science, especially the earth lithosphere. As has been disclosed by Mc Connell \& Khatrien (2011), motivation becomes one influence on the success of learning activities. The application of researchbased materials can be seen in Figure 4.

The concept that can be explained through Figure 4 is the structure of the subsurface layer and the potential for ground movement disasters. Based on the phenomenon seen during the learning activity, visualization in Figure 4 facilitates the students to understand the relationship of the subsurface structure of earth, the composition of the subsurface (clay content shown by the resistivity value), the geometry of the slip to the vulnerability of earth movement disasters. Where motion of the soil is one of the important concepts in the material of the earth's lithosphere.

In line with Werts \& Hinnov's expressions (2011) which states that the visualization of the data processing using matlab can help showing the interrelationship between variables in the insolation phenomenon (latitut relationship and insolation magnitude) then the visualization of geoelectric data processing in Figure 4 above can facilitate to understand several concepts simultaneously.

The visualization of Bengkulu rill condition that is vulnerable to soil movement in learning activities also provides more insight into 
natural disasters and how to adapt and mitigate. In line with research conducted by Rusilowati et al. (2015) which states that integrated physics learning natural disaster can improve local wisdom. Kortz \& Kraft (2016) stated similarly, the support of research projects (research science) in learning activities provides benefits such as improving understanding of learned concepts supported by the research experience, improving skills and motivation. The combination of scientific research and learning activity is becoming a trend in geoscience research.

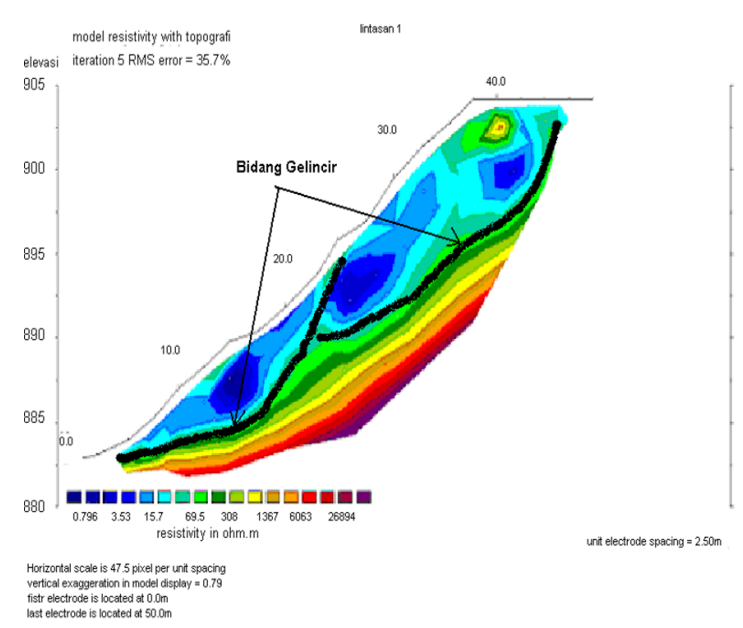

Figure 4. Visualization of subsurface crosssectional areas prone to soil movement (Johan, 2007).

Lectures with focus on classroom interaction and conceptual visualization aided by various media can train and improve students' reasoning ability. The interactions that are formed in learning activities allegedly give a positive impact and encourage greater curiosity. Animation that visualizes concept not observed directly can present the relationship and linkages between variables and concepts in building a phenomenon related to earth lithosphere and raise students' curiosity and supported by interactive atmosphere suspected to be a collaboration that supports students to train the ability in logic-thinking and understanding the concepts during the learning process. Based on the results of the study, after the implementation, most of the students are able to explain the problems in the context of litosphere material with comprehensive analysis supported by the relevant principles, theories, laws or definitions on the problem which becomes the question by following deductive-inductive rules. Students are able to connect the various concepts in describes a natural phenomenon.

\section{Spiritual Attitude}

The spiritual attitudes of this research are based on the competence of religious attitudes in the general description of the Indonesian National Qualification Framework which is then translated into several indicators adapted to the character of the Earth and Space science concept. Spiritual attitudes that will be implanted in this research is attitudes related to awareness and belief in the nature of the God, for examples nature of The Creator, The Almighty, The Maintainer, The Equitable, The Reckoner, etc. The questionnaire analysis used to find out the students' spiritual attitudes after the implementation of the Earth and Space science lecture program indicates the existence of spiritual attitude in the learning activities. The result of questionnaire for the attitude aspect of $\mathrm{s}$ piritual attitude can be seen in Table 8 .

Table 8. Quesioner 1

\begin{tabular}{|c|c|c|c|c|}
\hline \multirow{3}{*}{$\begin{array}{l}\text { Total re- } \\
\text { sponse for } \\
\text { all indicators }\end{array}$} & \multicolumn{2}{|c|}{ No } & \multicolumn{2}{|r|}{ yes } \\
\hline & 1 & 8 & 9 & 10 \\
\hline & 0 & 0 & $1.6 \%$ & $98.4 \%$ \\
\hline
\end{tabular}

Table 9. Questioner 2

\begin{tabular}{lcc}
\hline Total response for all & yes & no \\
\cline { 2 - 3 } indicators & $100 \%$ & 0 \\
\hline Notes: "yes" indicates the & existence & of \\
spiritual attitude in learning & & \\
& &
\end{tabular}

Based on the above questionnaire results show that more than $90 \%$ of students showed the existence of a spiritual attitude in the form of belief in the nature of God in the learning activities of litosphere material that has been done. As for the recapitulation result of the open ended test about the implantation of spiritual attitude, the students feel their awareness of divine nature increases after following the EES which has been implemented. According to students the activities or things that make their consciousness increase after the learning activities in general are the values expressed through the various phenomena in the earth lithosphere and the chain questions given at the end of the learning activities. The chain question ends in a question whose answer goes back to the creator's power because of the limited human knowledge. Here are some recapitulation results of the stdents' spiritual attitude analysis based on answers to open- ended test: Earth and Space scien- 
ce concept/natural phenomena presented in the learning activities also discuss the value and meaning behind the EES concept/natural phenomena. Conformity, complexity, and precision everything in nature raise students' awareness about God the Almighty, the Creator ; visualization shown in learning activities can visualize terrestrial phenomenon which is so great that add a sense of belief in the nature of God the Almighty ; the chain of questions that ultimately can not be answered scientifically by the students add to the awareness of the nature of the God.

Based on the results of questionnaires and open ended questionnaires conducted qualitatively shows that according to the student exploration of spiritual values in the form of belief in the nature of God gives a positive impact on the student's spiritual aspect. The implantation of spiritual values according to the students is obtained when the spiritual values on various lithosphere concepts are presented in the learning activities. The spiritual value of divinity is explored in various phenomena in earth lithosphere learning. Isnaini (2012) reveales that science teachers need to link learning with the religious side. An example of extracting these values in a learning activity can be seen in Figure 5.

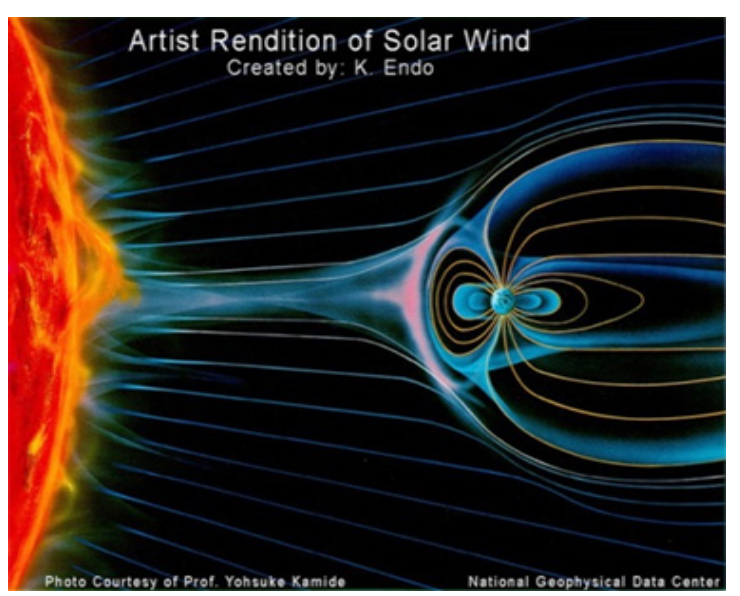

Figure 5. Example of exploration concept for the embedding of spiritual aspects (source: national geophysical data center).

The concept of geomagnet which is one of the important concepts in the earth lithosphere is explored to instill a spiritual aspect of belief in the God. The benefits of geomagnets that can be protective of the earth from various radiation and solar storms are the power of God to protect his creatures. If this is not explored it is possible students will understand the con- cept well but not touched its spiritual aspect. This kind of activity in earth lithosphere learning is thought to have a positive impact on embedding of the student's spiritual aspect. In line with Karwadi's research (2008) reveales that the integration of science and religion in the learning activities occurrence of complementation, comparison, certification, and verification. The concept of science in the break-down to present the concept of divinity. In addition, the results of the analysis show that interactive activities in class to discuss a phenomenon that is done by providing chain questions from which can be answered scientifically based on the concepts that have been studied and to the questions that can no longer be answered using the concept that has been studied have a positive impact on the spiritual aspect. An example of instill the spiritual aspect through a serial question can be seen in Figure 6.

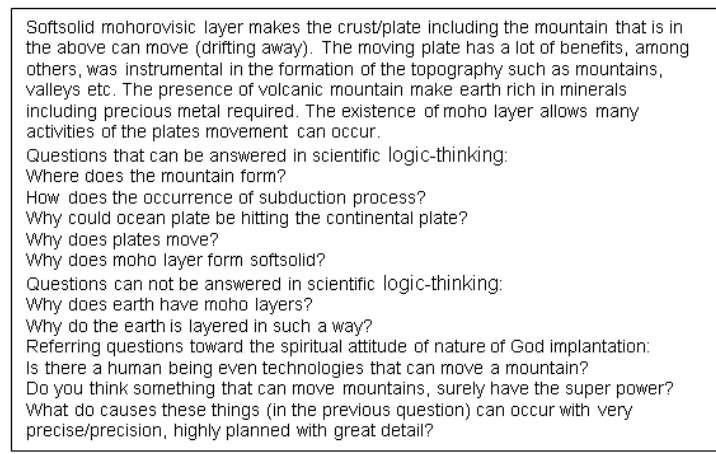

Figure 6. Example of implantation spiritual attitude through a chain questions

The chain questions in this interactive activity make students feel that there is a process that leads them to understand the natural phenomenon from the other side, that is from the spiritual side. Natural phenomena that occur or are created have a specific purpose. In general, the results of questionnaires and open-ended questionnaires showed that learning earth lithosphere overall not only affects increasing students' reasoning ability and mastery of concepts but also touches students' spiritual aspects. Based on the literature study, it is not often found similar reports on the integration of spiritual values in the study of science, especially earth and space science.

\section{CONCLUSION}

Based on the analysis of research results it can be concluded that after the implementation of earth lithosphere learning program 
through interactive conceptual use of visualization potentially increase students' logic-thinking and mastery of concepts and instill a spiritual attitude related to belief in the nature of God. It can be seen from the $\mathrm{N}$-gain value of reasoning of 0.69 in the medium ( upper-medium ) category and the concept gain $\mathrm{N}$-gain of 0.59 in the medium category. Visualization gives the concept details (phenomenon) clearly create curiosity and questions from students. Visualization used is also capable shows relationship of various variables or concepts in a terrestrial phenomenon. Implantation of spiritual attitude in learning activity is done through exploration of divine values in various phenomena in the earth lithosphere and giving of a chain questions.

\section{ACKNOWLEDGEMENT}

This research was funded by the Ministry of Research and Technology and Higher Education (Ristek-Dikti ) through Doctoral Dissertation grant fund. Contract No. 044 / SP2H / LT / DRPM / 2016, February 1, 2016 by Henny Johan.

\section{REFERENCES}

Ainsworth, S. (1999). The Function of Multi Representation. Journal of Computers and Education. 33, 131-152.

Bayong, T. H. K. (2012). Manusia dan Alam Semesta. Bandung: Institut Teknologi Bandung.

Bayong, T. H. K. (2014). Keajaiban Planet Bumi. Bandung : Institut Teknologi Bandung.

Bowen, C. W. (1998). Item Design Considerations forComputer-Based Testing of Student Learning in Chemistry. Journal of Chemical Education. 75(9), 1172-1175.

Carolan, J., Prain, V., \& Waldrip, B. (2008). Using representation for teaching and learning in science. Teaching Science, 54(1), 18-23.

Creswell, Jhon W., \& Clark, Vicki L. Plano. (2007). Designing and Conducting Mixed Methods Research. USA : Sage.

Costa, A. L. (1988). Developing Mind : A Resource Book for Teaching Thinking. Alexandria : ACCD.

Doyan, A., \& Sukmantara, I. K. Y. (2014). Pengembangan Web Intranet Fisika untuk Meningkatkan Penguasaan Konsep dan Kemampuan Pemecahan Masalah Siswa SMK. Jurnal Pendidikan Fisika Indonesia. 10(2), 117-127.

Ellwein, A. L., Hartley, L. M., Donovan, S., \& Billick, I. (2014). Using Rich Context and Data Exploration to Improve Engagement with Climate Data and Data Literacy: Bringing a Field Station into the College Classroom. Journal of
Geoscience Education. 62, 578-586.

Ismawati, F., Nugroho, S.E., \& Dwijananti, P. (2014). Penerapan Model Pembelajaran Conceptual Understanding Procedures untuk Meningkatkan Curiosty dan Pemahaman Konsep Siswa. Jurnal Pendidikan Fisika Indonesia. 10(1), 22-27.

Isnaini, Rahma Yulia. (2012). Meningkatkan Nilai-Nilai Ketuhanan Melalui Pelajaran Kimia Materi Struktur Atom Untuk Menumbuhkan Karakter Super Siswa. Prosiding Seminar Nasional Kimia, Universitas Negeri Surabaya.

Jee, B. D., Uttal, D.H., Gentner, D., Manduca, C., Shipley, T. F., Tikoff, B., Ormand, C. Y., \& Sageman, B. (2010). "Commentary: Analogical Thinking In Geosciences Education". Journal of Geoscience Education. 58(1), 2-13.

Johan, H. (2007). Penentuan Kedalaman Dan Geometri Bidang Gelincir Pada Daerah Rawan Gerakan Tanah. Skripsi tidak diterbitkan. Bengkulu : MIPA UNIB.

Joley, A., Lane, E., Kennedy, B., Seneclauze, \& . Frappe, T. P. (2012). SPESS: A New Instrument for Measuring Student Perceptions in Earth and Ocean Science. Journal of Geoscience Education. 60(1), 83-91.

Kali, Y. (2003). A Virtual Journey Within The RockCycle: A Software Kit For The Development Of Systems-Thinking In The Context Of The Earth's Crust. Journal of Geoscience Education. 51(2), 165-170.

Karwadi. (2008). Integrasi Paradigma Sains dan Agama dalam Pembelajaran Aqidah (Ketuhanan) (Telaah Teoritis dari Perspektif Kurikulum Integratif). Jurnal Penelitian Agama. 17(3), 516-536.

Kastens, Kim. (2010). Commentary: Object and Spatial Visualization in Geosciences. Journal of Geoscience Education. 58(2), 52-57.

Kortz, K. M. \& Katrien J. van der Hoeven Kraft. (2016). Geoscience Education Research Project: Student Benefits and Effective Design of a Course-Based Undergraduate Research Experience. Journal of Geoscience Educatio. 64(1), 24-36.

Lowe, Richard. (2004). Interrogation of A Dynamic Visualization During Learning. Learning and Instruction. 14, 257-274.

Mc Connell, David, Khatrien, J.V.H.K. (2011). Affective Domain And Student Learning In The Geosciences. Journal of Geoscience Education. 59(3), 106-110.

Meij, Jan van der \& Ton de Jong. (2003). Learning With Multi Representations : Supporting Students' Translation Between Representations In A Simulation-Based Learning Environment. Paper presented at the EARLI conference 2003, Padua, Italy, August 26th.

Meltzer. (2002). The Relationship Between Mathematics Preparation and Conceptual Learning Gain in Physics: Hidden Variable in Diagnos- 
tic Pretest Scores. American Journal Physics. 70(12), 1259-1268.

Miller, Brian W., \& Brewer, William F. (2010). Misconceptions of Astronomical Distances. International Journal of Science Education. 32(12), 1549-1560.

Newhouse, C.P., Lane, J., \& Brown, C. (2007). Reflecting on Teaching Practices Using Digital Video Representation in Teacher Education. Australian Journal of Teacher Education, 1(12).

Prain, Vaughan., Russel Tytler., \& Suzanne Peterson. (2009). Multi Representation in Learning About Evavoration. International Journal of Science Education. 31(6), 787-808.

Rusilowati, A., Supriyadi, A. Widiyatmoko. (2015). Pembelajaran Kebencanaan Alam Bervisi SETS Terintegrasi dalam Mata Pelajaran Fisika Berbasis Kearifan Lokal. Jurnal Pendidikan Fisika Indonesia. 11(1), 42-48.

Sibley, D. F. (2009). A Cognitive Framework for Reasoning with Scientific Models. Journal of Geoscience Education. 57(4), 255-263.

Smith, Gary A. \& Shannon Belle Bermea. (2012). Using Students' Sketches to Recognize Alternative Conceptions About Plate Tectonics Persisting from Prior Instruction. Journal of Geoscience Education. 60(4), 350-359.
Smosna, Richard \& Kathy R. Bruner. (2007). Toward the Improvement of Reasoning and Writing Skills in Sedimentary Geology. Journal of Geoscience Education. 55(1), 17-21.

Soesanto, H. (2009). Pembelajaran System Koloid dengan Multiple Representasi untuk Meningkatkan Kemampuan Berpikir Kritis Siswa SMA. Tesis tidak diterbitkan. Bandung : Magister Pendidikan IPA UPI Bandung.

Sunderlin, David. (2009). Integrating Mapping of Global-Scale Processes and Patterns on Imaginary Earth Continental Geometris : A Teaching Tool In An Earth History Course. Journal of Geoscience Education. 57(1), 7381.

Sutopo \& Waldrib, B. (2014). Impact Of A Representational Approach On Students' Reasoning And Conceptual Understanding In Learning Mechanics. International Journal of Science and Mathematics Education. 12, 741-765.

Werts, Scott \& Linda Hinnov. (2011). A Simple Modeling Tool and Exercises for Incoming Solar Radiation Demonstrations. Journal of Geoscience Education. 59, 219-228.

Wittman, M.C. (2006). Using Resource Graphs to Represent Conceptual Change. Physics Review : Physics Education. Res. 2,020105 